\title{
THE ETERNAL DEBATE BETWEEN REALITY AND FICTION: THE PERIPLUS OF HANNO "THE NAVIGATOR"
}

\section{Introduction}

The Periplus of Hanno narrates the development of an expedition carried out at some point in Antiquity by a Carthaginian fleet led by a "certain" Hanno along the Atlantic coasts of North Africa.

During his journey (and according to the Periplus), several enclaves were founded and part of that geographic area was explored and colonized. Despite the shortness of the story, composed of only eighteen paragraphs, it has powerfully caught the attention of researchers, giving rise to a "Hannonian issue," that has caused debates and oppossed postures regarding some aspects of the narration.

The Periplus, and everything related to it, constitutes one of the most recurrent topics of study (and discusión) of the Phoenician-Carthaginian presence on the North African Atlantic coasts. Although the progress made through analyses and studies carried out on the Periplus is important, unfortunately they are scarce compared to the abundant literature generated (Mederos and Escribano, 2000: 77-78).

\section{On the Periplus of Hanno}

In a medieval manuscript written in Greek, dated between the 9th and 10th centuries, known as the Codex Palatinus Heidelbergensis gr.398, in pages 55r-56r there are the eighteen paragraphs that compose the narrative of the Periplus. Some scholars consider this medieval Greek version a reliable transcription of the monolith inscription that Hanno himself erected in the temple of Moloch-Baal in Carthage after his return. In the face of this stance, there is an ever-increasing critical current that calls into question the truthfulness of the story, and focuses on the study of the Periplus from Greek literature due to its nature.

Regarding to its structure, Desanges (1978) considers that it is possible to differentiate two parts:

1. paragraphs 1 to 8 : thanks to several comparative analyses of other similar narratives considered as Phoenician expeditions carried out in order to expand their knowledge of both the Iberian and North African Atlantic coasts, the majority of scholars give the Periplus historical veracity. According to Strabo, these Phoenician expeditions gave rise to the foundation of Gadir (Estr. Geography. III. 5.5), as well as other sites, including those of Himilco along the Portuguese coast and Northern Europe as Avienus states in his Ora marítima (Avien. Pray.V.117), same as Pliny The Elder in his Naturalis Historia (Plin., N.h. II, 169). The most useful text to establish such comparisons is the Pseudo Scylax and its description of the African coasts and other Phoenician expeditions in the same area. 
2. paragraphs 9 to 18 : the facts narrated in these have been considered by many scholars as additions made during Hellenistic times (or later), where fabulous elements, mythical references and imaginary places are mixed. In this part there are literary elements comparable to other Greek authors such as Herodotus or from the Hellenistic period (Desanges, 1978: 39-85; González Ponce, 2008: 111-113).

\section{Opinions on the Periplus}

González Ponce considers that the first part of the narrative is dominated by an eminently colonizing activity, while the second includes the exploration of the coastal area at the south of the island of Cerne (2010: 762). This opinion is shared by the majority of scholars, including strong advocates such as Germain, who admitted that the Periplus might be authentic according to what is exposed in paragraphs 1 to 6 and despite several manipulations and additions done in later times (1957: 206, 215-216, 225,236 and 238).

According to Peretti, the Periplus is one the most important examples of PhoenicianCarthaginian navigation techniques. This scholar bases his opinion on the presence of two essential elements contained in the Periplus: the geographical descriptions of the African coasts and the calculation of the daily travelled distance (González Ponce, 1995: 62-64).

There are scholars such as Segert, who claim that the Phoenician evidence is clearly seen in the Greek version of the Periplus, supporting his statement in the places mentioned throughout the narration and literary style. Nonetheless, there are some inconsistencies due to the extreme fidelity of the Greek versión and later Hellenic additions (1969: 507-512). Blomqvist does not share such view, and for him there is no data to ensure that the Greek version is an exact copy of the original text, since there is nothing in it that does not correspond to the particularities of Greek language (1979: 15).

Regarding the identity of Hanno, there seems to be consensus in considering him a shophet, and therefore a member of one of the most powerful aristocratic Carthaginian families. For some scholars, Hanno is just a synonym of "Carthaginian", extensively used by the anonimous autor of the Greek versión (Musso,1989: 959-960), or merely the Greek term used to identify an experienced sailor, which would be a literary strategy to give credibility to the story (Gómez Espelosín,1996: 103; 2000: 149-150). Germain finds the lack of identifying information on Hanno somewhat suspicious if we take into consideration that, theorically and according to the Periplus, he belonged to a very distinguished Carthaginian lineage (1957: 226 and 230). According to Herodotus, the author of the Periplus was Amilcar's father, the general defeated in Himera in 480 BC (Herod. VII, 165). In Justinus' view, Hanno was none other than Himilco's brother (Just. XIX, 2).

Another point under discussion is the date on which the expedition should have taken place. Pliny provides an essential data to establish a likely date by stating that it took place during Carthage's peak, at the same time of Himilco's journey (Plin. N.h. II, 
169). It has traditionally been considered that Hanno's expedition must have developed between the 7th and 4th centuries BC (Desanges, 1978: 85, 292; Villalba i Varneda, 1986: 38-39; Musso, 1989:955), but such broad chronology makes difficult to safely determine a specific date.

Many scholars are in favor of setting as the most likely date between 510 - 509 BC, at the time of the First Roman-Carthaginian Treatry, which involved the closure of the Strait of Gibraltar by Carthage and the control of trading routes towards the Western Mediterranean and North African coasts (Kluge, 1829: 1-4; Schrader, 1990: 98, 107). Some others have identified Hanno as the son of the aforementioned Amílcar, so the date of the expedition should have been around 470 BC (Garzón Díaz, 1987:82; García Moreno, 1989: 238; Cordano, 1992: 5 and 11; Martín García, 1992: 65; Ottone,2002:565), coinciding with a change in Carthaginian foreign policy, focused on strengthening its control over North Africa and the sea routes leading to the Atlantic coasts of North-Western Europe. A third group considers that Hanno's travel took place, and following Pliny, between the signing of the Second RomanCarthaginian Teatry of 348 BC and the outbreak of the First Punic War in 264 BC.

With regard to the expedition itself, a large majority of scholars accept their authenticity, but nonetheless, no consensus has been reached regarding its final destination and objectives. Supporters of a positivist approach consider the possibility that it was a "long journey" and that Hanno had reached someplace between Sierra Leone and Gabon (Schrader, 1990: 108 and 145-146, Cordano, 1992: 5-6; Martin Garcia. 1992: 80, Jabouille, 1994:57), or even having circumnavigated the African continent (Oikonomides, 1977: 11-12). On the purpose, there is the possibility that it had been a genuine colonizing expedition, as can be read in the first paragraph of the Periplus, a fact that would be in line with the founding activity reflected in the first part of the narration (Schrader, 1990: 108; Cordano, 1992: 5-6), although commercial reasons, as Desanges (1999: 23-24) or Mederos and Escribano (2000: 89-91) point out, should not be ruled out.

Considering the technical characteristics of the vessels that possibly were part of Hanno's fleet, there are researchers who question their seafaring capabilities and the possibility of a "long journey" (Mauny, 1955:96-97; 1960: 1-22; 1970: 98-101; 1978: 298), and at the most thay could have sailed until Cape Bojador. According to Lonis, Carthaginian vessels had better seafaring capabilities than we thought at first (1978: 148-149, 159-160).

The absence of conclusive data to accept the hypothesis of a "long journey" has led to a similar current advocating a "short journey" in recent times, arguing that Hanno's expedition took place on the north-western Atlantic coast of present-day Morocco, reaching, at most, Cape Solunte (present-day Cape Spartel). That would allow to locate most Punic foundations made in the area around the Lixo River (Rebuffat, 1988: 85-86). Thanks to the discovery of some archaeological evidences, it has been noted that the Punics reached locations much further south than had been thought, such as Mogador Island, identified as the mentioned Cerne in the Periplus as Euzennat 
suggests (1994: 563-578). Others researchers as Lopez Pardo (1991:62-63) or Mederos and Escribano (2000: 92-93), think that Hanno reached as far as the Sous area.

Germain had already expressed doubts about the Periplus after analyzing the possible motivations of the expedition, and he thinks that it was due to colonizing reasons, which Germain believes was entirely consistent with the view of a Greek, who would not conceive any other reason for such an expedition. Gómez Espelosín considers the narration a work of fiction due to technical impediments and lack of development of complex navigation, the lack of conclusive archaeological evidences and the inconcretion of the economic causes that led to this expedition (1996: 107-109;2000: 152-154). In a similar vein, García Moreno has stated that the Periplus is just a paradoxographic exercise based on the activities of ancient Mediterranean peoples south of Cape Juby (1989: 240-242).

\section{Conclusions}

The study and research of the Periplus constitutes one of the most paradigmatic examples of "speculative archaeology" and for scholars as Mederos and Escribano, much of the literature that it has generated only proposes hypotheses that are difficult to check archaeologically (2000:91).

During the $20^{\text {th }}$ century the amount of studies on the Periplus reached a great number and brought different (and even antagonistic) interpretations and conclusions about it. The emergence of a skeptical current that questioned its authenticity, arguing that it is only a mere account devised by Carthaginians in order to hide information to their potential competitors. Also, and according to that current, it is possible to observe some obvious loans taken from authors such as Herodotus or the Pseudo-Aristotelian Book of Wonderful Stories (Gozalbes Cravioto, 2014: 509).

Since Germain started that skeptical trend based on philological elements contained in the Periplus, other scholars have delved into their own analysis, highlighting the existence of some problematic terms, as well as the late character of the later version of the Periplus, whose characteristics do not correspond to a 5th century B.C. composition. Such arguments have been questioned by researchers such as Blomqvist (1979) or Martín García (1992), that put emphasis on the presence of elements that are fully consistent with Classical Greek language. According to Desange, it is very likely that the original manuscript reflected true facts, but they have been overshadowed or manipulated to magnify the narration, or simply due to the transmission of the text (Gozalbes Cravioto, 2014: 510).

However, during Antiquity some authors questioned the authenticity of the Periplus, especially when it is stated that several Punic colonies were established along the Atlantic coast of present-day Morocco, and whose existence was unknown at the time. Something similar happens when identifying many of the places mentioned during the expedition, especially those located south of Cape Juby. 
In the opinion of Mederos and Escribano, the difficulties to corroborate the location of them do nothing more than increase the number of theoretical speculations, which, in the opinion of both authors, are hardly contrasting archaeologically (2000: 91). The lack of conclusive archaeological evidence from various archaeological surveys carried out in the area between Noun and Draa rivers (Euzennat, 1960: 564) and on the island of Herné, identified as Cerne, resulted in the search for an alleged Punic settlement in it (Great Aymerich, 1979; Desanges, 1981) is, for many authors, a good example of the disconnection between bibliographical and archaeological investigations (Mederos and Escribano, 2000: 92).

A main reason to question the veracity of the Periplus is the lack of information regarding the foundations that took place during Hanno's journey, although, according to Pomponius Melus (III, 90) or Pliny (N.h.II, 168), who could read the original text first-hand, those colonies existed except those located in Equatorial Africa. The existence of such Punic colonies has not been proved, same as the temple that Hanno erected in Cape Soloeis. It is believed that the place that best corresponds with Cerne is Mogador, where have been found remains of Phoenician presence dated from the $8^{\text {th }}$ century B.C. being fully active between 750 and 500 B.C., being so far the southernmost point where solid archaeological evidence has been found. However, it would not be impossible to have sailed beyond Cape Juby, as Herodotus says when he mentions the Periplus of Necao (Herod. IV, 42) and some numismatic findings in Equatorial Africa suggest. Nonetheless, there is no solid archaeological evidence that allow to support the hypothesis of a "long journey," and most likely Hanno's expedition took place along Morocco's Atlantic coast.

Although there are not so many fantastic elements in the Periplus, but a sober description of places and facts, through time the original text was modified with the addition of clearly fictional elements that should not be taken as a reason to dismiss the Periplus as a whole. It is possible that it has lost some of its original veracity, but there is archaeological evidence and even without it, some authors as Strabo (III. 2,14) supported its authenticity. It should be taken into consideration that long-distance navigation were carried out earlier and, with greater profusion, by Phoenicians than by Greeks, and the exchange of information between them.

There is no doubt that the Periplus will continue to provoke debates and interpretations, and there will be no shortage of those who question its validity, while others will speak out in the opposite direction. In Dominguez Monedero's opinion, right now no one can provide solid arguments or conclusions to enable a consensus that satisfies all scholars (2010:92). However, and thanks to archaeological findings, it has been possible to study the Periplus differently, a text that sometimes has been examined with excessive hardness (Tejera and Chávez, 2005:170). Probably a more critical reading of the narration, using historical, philological, geographical and archaeological evidences, will help us to fully understand and appreciate its historical and cultural value. 


\section{BIBLIOGRAPHY}

- DOMINGUEZ MONEDERO, A.J. (2010) "El viaje de Hanón de Cartago y los mecanismos de exploración fenicios" en: MARCO SIMON, F.; PINA POLO, F.; REMESAL RODRIGUEZ, J. (eds.) Viajeros, peregrinos y aventureros en el Mundo Antiguo; Barcelona: Universidad de Barcelona; pp. 77-95.

- GOMEZ ESPELOSIN; F.J. (2006) Viajes de verdad, viajes de mentira: literatura de viajes del periodo helenístico; Revista de Filología Románica, anejo IV; pp. 59-75.

(2013) "Realidad y ficción en los relatos de viaje de la Antigüedad" en: NAVARRO DOMINGUEZ, E. (ed.) Imagen del Mundo: seis estudios sobre literatura de viajes; Huelva: Universidad de Huelva; pp. 17-41.

- GONZALEZ PONCE, F.J. (2008) "Periplo de Hanón” en: GONZALEZ PONCE, F.J. Periplógrafos griegos I: Épocas Arcaica y Clásica (Periplo de Hanón y autores de los siglos VI y V a.C.); Zaragoza: Prensas Universitarias de Zaragoza; pp. 75-115.

Periplo de Hanón (11-18)? En: ALBALADEJO, M (ed.) Viajes y relaciones interculturales en la Antigüedad; Guadarrama: Ayuntamiento de Guadarrama; pp. 87-101.

(2010) Veracidad documental y deuda literaria en el Periplo de Hanón, 1-8; Mainake XXXII ; pp. 761-780.

- GOZALBES CRAVIOTO, E. (2014) En torno a la transmisión antigua del Periplo de Hannón; Anuario de Estudios Atlánticos, $n^{\circ} 60$, pp. 489-513.

- LOPEZ PARDO, F. (1991) "El Periplo de Hanón y la expansión cartaginesa en el África Occidental", Trabajos del Museo Arqueológico de Ibiza y Formentera $n^{o}$ 25; pp. 59-72.

- MEDEROS MARTIN, A.; ESCRIBANO COBO, G. (2000) El periplo norteafricano de Hanón y la rivalidad gaditano-cartaginesa de los siglos IV-III a.C., Gerión n $n^{o}$ 18, pp. 77-107.

- SCHOFF, W.H. (1912) The Periplus of Hanno: a voyage of discovery down the West African coast by a Carthaginian admiral of the fifth century B.C.; Philadelphia: The Commercial Museum.

- TEJERA GASPAR, A.; CHAVEZ AlvareZ, Ma.E. (2005) El Periplo de Hanón: ¿una realidad falseada?, en: ARUDA, M. (ed.) Actas del VI Congresso Internacional de Estudios Fenicios e Púnicos; Lisboa: Universidade de Lisboa; pp.166-171. 